\title{
Impact of Wetland Development and Degradation on the Livelihoods of Wetland-Dependent Communities: A Case Study from the Lower Gangetic Floodplains
}

\section{Tiasa Adhya}

The University of Trans-disciplinary Health Sciences and Technology

Sayan Banerjee ( $\sim$ sayan.workspace@gmail.com )

National Institute of Advanced Studies https://orcid.org/0000-0002-2292-0567

\section{Research Article}

Keywords: degradation, development, ecosystem services, Lower Gangetic Floodplain, oral testimonies, wetlands

Posted Date: January 6th, 2022

DOI: https://doi.org/10.21203/rs.3.rs-1204186/v1

License: (c) (1) This work is licensed under a Creative Commons Attribution 4.0 International License. Read Full License 


\section{Abstract}

Wetland ecosystem services exceed those provided by terrestrial ecosystems and their 'wise use' has implications for achieving sustainable development goals. Yet we have lost almost $87 \%$ of wetlands since pre-industrial times with losses projected to be much higher by 2050 in developing economies, particularly in Asia. Little is known about how this loss impacts people's dependency at local scales in human-dominated landscapes. We identified 18 ecosystem services of Dankuni wetlands located in the Lower Gangetic Floodplains by analysing oral testimonies of wetland-dependent villagers. The ecosystem services include 12 provisioning services and two each of regulatory, cultural and supporting services. Farming and use of wetland products including molluscs, fuelwood, fodder, fibre and fish was found to subsidize living costs and provide diverse livelihood options to local residents. Encroachment of wetlands by factories and blockage of its riverine connection was reportedly degrading the wetland's quality and eroding its ecosystem services since the last 20 years and especially since the last three years. In years of excessive and unseasonal rainfall such as during the study year, post-monsoon farming was severely impacted. We portray the human costs of wetland development which will affect vulnerable sections the most, especially landless widows and older residents. Respondents believed that it was possible to rejuvenate the wetland by restoring its riverine connections but stressed that local politicians had vested interests in supporting its degradation. We strongly assert the need to increase government accountability for protection of wetlands amidst a determined pursuit of development at the cost of sustainability.

\section{Introduction}

Healthy functioning wetlands provide a range of ecosystem services that far outweigh those provided by terrestrial ecosystems (Gardner and Finlayson 2018). The services range from providing food security (McCartney et al. 2010) and mitigating climate change (Mitsch et al. 2013; Fennessy et. al. 2018) to regulating water and sediment quality, pollutants and nutrients (Chalov et al. 2017) and providing cultural and spiritual inspiration (Pedersen et al. 2019). From an economic perspective, the global value of these wetland-based ecosystem services is worth USD 70 billion per year (Brander and Schuyt 2004). Wetlands are vital for maintaining the most fundamental nexus between water, food and energy (Russi et al. 2013) and to critically link human livelihoods with sustainable development since agriculture and water-related services might be severely impacted due to wetland loss (Gardner and Finlayson 2018; McCartney et al. 2010). Thus, it is globally acknowledged that wetlands provide ecological infrastructure to meet a range of international policy objectives. Hence, the need to integrate their 'wise-use' into national policies in order to achieve the transition to resource efficient, sustainable economies is imperative (Ramsar Convention Secretariat 2016). In fact, wetlands are central to achieving Sustainable Development Goals (SDGs); with 'improving water quality', 'sustainable management of resources' and 'efficient resource consumption' being identified as universal priority targets to achieve sustainable development (Jaramillo et al. 2019). This is why balancing between wetland conversion, sustainable utilization and conservation 
has been emphasized particularly in developing countries in which wetlands are being rapidly degraded (Turner 1991).

Wetlands have been facing maximum exploitation in the post-industrialization era with recent estimates suggesting an $87 \%$ decline in global wetland area since pre-industrial times (Walpole and Davidson 2018). Infrastructure construction-led wetland conversion and industrial waste disposal in the wetlands were identified as important proximate causes of global wetland degradation (Van Asselen et al. 2013; Gardner and Finlayson 2018), particularly in the developing countries. Over $80 \%$ of untreated wastewater is released into wetlands globally (WWAP 2012; UN-Water 2015) with lower middle-class countries treating $28 \%$ and low-income countries treating $8 \%$ of their wetlands (Sato et al. 2013). Although wetland loss in developing countries was historically lower than the developed countries, the loss is projected to be much higher in future in the former, particularly in Asia, with a predicted increase of urban population by 1.4 billion by 2050 (United Nations 2008; Hettiarachchi et al. 2015), thereby leading to increased risk of environmental disasters and livelihood loss (Smardon 2009; Azarath et al. 1988; Ghosh and Sen 1987). Water pollution is also increasingly worsening the conditions of all Asian rivers (Davidson 2014; WWAP 2017).

The Ramsar Convention for wetland conservation has foregrounded wetland governance in the global environmental policy domain, but the Asian scenario highlights the convention's inadequacy in dealing with threats that originate from urban development policies shaped largely by broader political-economic forces of developmentalism (Hettiaracchi et al. 2015). In India, wetlands are protected under a national wetland law - Wetlands (Conservation and Management) Rules 2017 (Ministry of Environment, Forest and Climate Change 2017) under the overarching Environment Protection Act, 1986, yet various types of wetlands, for example, marshlands are categorized as 'wastelands' under national development policies (National Remote Sensing Centre 2010). Even though a law supersedes a policy, rapid urbanization at the cost of wetlands continues, therefore becoming the leading cause of the loss of ecosystem services in the Gangetic Plains[1](Das and Das 2019). For example, the East Kolkata Wetland (EKW), a Ramsar site, located within the Lower Gangetic Floodplains, has contracted significantly due to encroachment of built up area in the metropolitan city of Kolkata resulting in reduced productivity and wild fish stocks (Kundu and Chakraborty 2017).

The social costs of developing peri-urban wetlands in this floodplain other than EKW, remain less studied. Damodar-Hugli interfluves[2] in the Lower Gangetic Floodplains has a wetland complex called Dankuni (Sinha et al. 2013) with dominant marshland vegetation in which one of the authors (TA) conducted populations surveys of Fishing Cat (Prionailurus viverrinus), a wetland-dependent wild cat species (Adhya et. al. 2011). The study emphasized the deleterious impact of industries and roads on the Fishing Cat habitat. Later, in 2012, a Public Interest Litigation (PIL)[3]was filed at the regional high court by non-government organisations as much of the wetland encroachment was happening without adequate land and environmental clearances (Adhya 2015). Further, marshlands are recognized as 'wetlands' under Wetlands (Conservation and Management) Rules 2017 (Ministry of Environment, Forest and Climate Change 2017), which prohibits alteration of its ecological character for development 
purposes. Local residents had also registered protests against the degradation (Adhya 2015). However, irrespective of litigations, protests and existence of environmental laws, the degradation of the Dankuni wetland complex continues, pointing towards vested powerful political-economic forces.

While examining habitat ecology of Fishing Cats, we started observing as well as documenting wetland dependency of local communities who resided near the wetland. It became imperative that without examining local community-wetland interaction, understanding of the socio-ecological importance of the wetland will remain unfruitful. With this background, the specific objectives of the study were to investigate - a) local resident's dependency on the Dankuni wetland complex, b) their perceptions of changes in the condition of the wetland, c) their perceptions of changes in their livelihoods and living due to wetland changes, d) their perceptions of political-economic forces as drivers of change, and, e) their perceptions towards addressing the threats to the ecosystem.

[1] Gangetic Plains constitute part of the Ganges Brahmaputra Basin

[2] Interfluves are elevated terrains between two rivers flowing in the same direction in the same drainage system

[3] PIL type litigations can be filed by any citizen in the court of law if the issue in hand affects public interest.

\section{Methodology}

\subsection{Study site}

We chose to conduct the study in a single village, Jhakari $(22.75 \mathrm{~N}, 88.29 \mathrm{E}$ to $22.75 \mathrm{~N}, 88.30 \mathrm{E})$, located on the fringes of the Dankuni wetland complex (see Fig. 1).

The Dankuni wetland complex is approximately $30 \mathrm{~km}^{2}$ in area and is perhaps one of the last contiguous marshy stretches in the Damodar-Hugli interfluves of the Lower Gangetic Floodplains. It is traversed by one of the busiest railways tracks of the region and is bounded with a national highway in the east.

The wetland complex is dominated by both tall and short emergent vegetation[4] which are visual cues of marshlands. It experiences seasonal inundation and flooding during monsoon (June-September) especially due to its connection with the river Ganges and starts drying up post-monsoon (October onwards). By summer (March-May), surface water is retained only in some depressions. The wetland is a popular birding site as it provides refuge to both resident and migratory birds throughout the year (Hazra et al. 2012). Apart from this, freshwater fishes, snakes, turtles, amphibians and various kinds of insects especially damselflies form a significant part of the faunal diversity. Mammals like mongoose, civets, Golden Jackal, Jungle Cat and Fishing Cat are also present. During the dry season (December to May), cultivation takes place in some portions (Hazra et al. 2012). Some areas of the wetland were converted 
for small-scale aquaculture farms. Local residents also collect grasses, wild flowers and stalks, plant parts, molluscs and wild fish from the wetlands.

Jhakari is a typical peri-urban village located in the fringe of the Dankuni wetland complex which is neither completely rural nor fully urban. It is well-connected by road and rail infrastructure and is located $35 \mathrm{~km}$ from the metropolitan city of Kolkata. The human population of the village consists of approximately 1000 families and the structure of the village society is heterogeneous with people belonging to both Scheduled and General Castes. Most people are Hindus and a small section of Muslims are also present who are economically poor and landless. Apart from few concrete houses built nearer to the main road, most houses are earthen with roofs made of straws, bamboo leaves, tiles etc. A narrow concrete road runs through the middle of the village. There is a primary health centre and a government sponsored play-school for children. No school or college is located in the village, to access which, students have to move or travel to nearby towns/villages.

\subsection{Methods}

Fieldwork was carried out in 2019-2020 and thirty seven semi-structured interviews, consisting of 7 female and 30 male interviewees were conducted through snow-ball sampling. The interviews were conducted in the local Bengali language. A villager was first approached and asked whether he/she was native to the village and could devote some time for the interview after which the motivation of the study was explained. It was also stated that their names would remain anonymous. Upon gaining consent, semi-structured interviews were conducted with the questions structured around the objectives described above. With the respondent's consent, the oral testimonies were recorded in a voice-recorder. Information was collected on their dependency on wetlands starting with leading questions such as do they farm, fish, collect anything from the wetland that helps them in their daily lives and provides them livelihood. Secondly, they were asked whether they perceived any change to the wetlands since their childhood. During the course of the conversation, we tried to understand how the change might have affected their livelihood and living. Thirdly, we examined their perceptions of threats to the wetland. Lastly, we asked 'if anything can be done to address the threats', 'if so what' and 'if any interventions were taken by local residents or the government'.

Most women denied participating in the interviews as either they were extremely busy with their daily household chores or they felt that the male member of the household was more knowledgeable to appear for an interview.

Later, the audio-recorded interviews were transcribed and translated. The transcripts were divided into broader themes like 'ecosystem services' which was further subdivided into 'provisioning', 'regulating', 'cultural' and 'supporting'. The other themes were 'impacts', 'reasons for degradation', and 'addressing threats' with the latter containing information on efforts to address threats to the wetland. Other relevant information was noted in the 'comments' section. In the results section we have extensively used people's testimonies but instead of using actual names, we have used the initials of their full name as an anonymised marker. 
[4] These plants are found in shore areas near waterbodies. Some plants are completely submerged, while some are rooted in the wetland soil, with their stems, leaves and flowers rising above the water.

\section{Results}

\subsection{Wetland Dependency of the study village}

We identified 18 ecosystem services from the oral testimonies (see Table 1) out of which 4 ecosystem services provided important sources of livelihood. 
Table 1

Types of ecosystem services provided by Dankuni wetlands

\begin{tabular}{|l|l|}
\hline Types of ecosystem services & Ecosystem services recorded \\
\hline Provisioning (12) & 1) Seasonal farming \\
2) Fish & 3) Edible wild flowers \\
& 4) Leafy vegetables \\
& 5) Mollusc \\
6) Fibre \\
7) Water \\
8) Mud \\
9) Bamboo \\
10) Jute-stick \\
11) Fuelwood \\
12) Fodder \\
\hline 1) Water purification \\
2) Flood regulation \\
\hline 1) Capacity to reflect \\
2) Recreation (children build mud-houses) \\
\hline 1) Fish nursery \\
2) Nutrient retention \\
\hline
\end{tabular}

\subsubsection{Provisioning services}

Twelve products including plants and animals, edible and non-edible were identified by the respondents which they obtain from the wetland (see Fig. 2). Interviewees commonly cultivated edible crops such as paddy, onion, ladies finger, spinach, coriander, beans, cow pea, Indian pea (see Table 2). Among these, paddy was the most important resource for local consumption as well as livelihood. The harvested rice is generally kept for consumption and the excess rice is sold at 1000-1300 INR[5]/bag with each bag containing $60 \mathrm{~kg}$ rice. 50 year old GB said "The paddy we harvest is good in quality, much more healthy and tasty than the rice provided at government ration shops which is often mixed with dirt and small 
stones," indicating that he felt a certain pride in harvesting his own rice. Another farmer, 43 year NT, further added that the rice from fair price shops costs around 32-33 INR/kg but his children refuses to eat it because of its poor quality. On the other hand, premium quality rice was reportedly too costly to afford. Onion and okhra were the two other commonly cultivated crops. KK, a 30 year old farmer, seemed happy with the significant profit returns from his piece of land after harvesting these crop types, "I spent 20,000 INR for harvesting onion and okhra but earned 80,000 INR. After harvesting the paddy, I planted jute in the same land. I spent 20,000 INR in labour again but earned 50,000 INR. For paddy, if I spend 10,000 INR in labour, I get back 26,000 INR."

Table 2

Commonly produced crops and their price

\begin{tabular}{|lll|}
\hline Name of Crop & $\begin{array}{l}\text { Average Selling Price } \\
\text { (INR/Kg) }\end{array}$ & $\begin{array}{l}\text { Average Selling Price } \\
\text { (USD/Kg) }\end{array}$ \\
\hline Coriander (Coriandrum sativum) & 70 & 1 \\
\hline Spinach (Spinacia oleracea) & 70 & 1 \\
\hline Beans (Phaseolus vulgaris) & 40 & 0.50 \\
\hline Indian Pea leaves (Lathyrus sativus) & 60 & 0.80 \\
\hline $\begin{array}{l}\text { Ladies Finger (Abelmoschus } \\
\text { esculentus) }\end{array}$ & 53 & 0.70 \\
\hline Onion (Allium cepa) & 30 & 0.45 \\
\hline
\end{tabular}

Bamboo and mud were frequently used wetland products for constructing houses. Bamboo was also used for making fish catching traps, broomsticks and baskets. These products provided additional sources of livelihood and were particularly useful when cultivation failed. 29 year old DD's crops failed in 2019 but he survived by selling fish catching traps for 250 INR and baskets for 50 INR.

For widows from the marginalized sections of the society who were also landless, molluscs provided the only source of livelihood. For them, providing for their children was economically challenging and they could overcome this hardship because they could collect products from the wetland and sell them. AK, who is a senior citizen now, reminisced how she went out searching for molluscs in waist-deep water in the wetland during the day accompanied by three to four other women. They felt for them on the soft mud underneath which by itself was a physically exhausting process. It did not end there as they had to wake up by $2 \mathrm{a}$.m. in the following morning and dress the molluscs in time. They then sold them for 80 INR/kg via middlemen who gave back 30-50 INR/kg. 60 year old SK rather preferred selling them door-todoor or by herself in the market and reportedly earned $200 \mathrm{INR} / \mathrm{kg}$. But did they still prefer to undertake this hardship once their children grew up and started earning for the family? Yes they did as it helped them remain independent as well as provided means to support their family when needed. As AK 
explained with a tone of clear confidence, "My sons look after me but I choose not to ask for money from them to cater to my needs and cravings." She also added that molluscs are packed with nutrition and are good for eyesight as was told to her by doctors."

Almost all respondents fished in the recent past (till 5 years ago). Many of them are still involved in fishing. Fish is caught by various methods. SK caught fishes with her bare hands rather than with fish traps or nets and reported that "Heteropneustes fossilis and Clarius batrachus are rare but if caught fetches good prices upto $1000 \mathrm{INR} / \mathrm{kg}$. Smaller fish like Cyprinus rubrofuscus can be sold for 200-300 INR/kg." Respondents also used fish traps made from bamboo and fishnets with various hole-sizes.

Fuelwood, fodder, edible plants and plant fibre are useful wetland resources in the village. BT, a 50 year old widow, was especially dependent on fuelwood collected from the swamp to run her small eatery which catered to farmers in the field and to factory workers. Indian Jointvetch (Aeschynmene indica), jutesticks and bamboo were used as fuelwood. Villagers also depended on swamp grass to feed their cows. Leafy vegetables and stalks of aquatic plants were widely collected for local consumption. Poorer people such as widowed women and older residents also sold them. Some respondents also collected Harsh Jointvetch (Aeschynmene aspera) which was used for making marriage gear for brides and grooms and for decorating religious deities. KK (30) reported the selling price to be 300 INR/bundle while SD (49) said that people earn 400-500 INR/bundle to even $1000 \mathrm{INR} /$ bundle during summer. Water from the swamp was reportedly used for irrigating farm plots. "If there is no swamp, then, water for agriculture will not be available anymore. The surroundings are drying up day by day," said said 32 year old PM.

Older residents also benefited from the wetlands as they could undertake less laborious tasks and were still able to support their families. "I cultivate a little bit of onion and take the cattle out to graze. I also collect edible plants from the swamp. At my age, that's as hard as I can work to support myself and the family. But I will not be able to do this if the swamp is lost and will have to depend on others for food."

\subsubsection{Regulating services}

From the oral testimonies, we identified two regulatory services of the wetlands - flood control and water purification. PM (32) explained "If the wetlands degrade, the waters in monsoon will flood our houses." HT (70) said "People who went to work in the swamp did not need to carry water with them because the swamp water was available. It was like filtered water."

\subsubsection{Cultural services}

Residents shared that the wetlands provided them with the opportunity to reflect on life while younger children enjoyed recreational activities. 49 year old SD shared how children in the village created doll houses and dolls made out of mud taken from the wetland whereas young adults used the wetland space as social bonding sites. On the other hand, the wetlands inspired reflection among interviewees evident in their words. 32 year old ST for instance stated how the swamp brings prosperity to them and gives them a chance to cultivate "food of self-respect".

\subsubsection{Supporting services}


We identified two supporting services which are nutrient retention and sustenance of fish stocks from the oral testimonies. 35 year old PS, for example, stated how the waterlogged lands became fertile after recession of the floods thus facilitating farming. 30 year old KK on the other hand explained how the wetland created a conducive environment for fish to breed in.

\subsection{Change in the wetland quality and its human cost}

Respondents perceived a steady degradation in the wetland's quality in the last 20 years with the trend worsening rapidly during the last three to four years. From their testimonies, it is apparent that this change has affected their livelihoods and living in significant ways.

58 year old ST stated that the swamp was four times bigger two decades back compared to the present extent. Majority of the respondents reported a reduction in the quantity of products obtained from the wetland. "Tides used to come into the swamp through the canal which connected it with Ganges bringing in a variety of fish like Bele, Koi, Singhi, Punti and their eggs," said 50 year old GB while describing how the wetland functioned in the past. Large sized prawns also used to be available which fetched significant monetary returns. Post-monsoon, the flood waters in the swamp would slowly recede through the canal into Ganges exposing nutrient-rich soil fit for harvesting. "Paddy like amon, neramon and beta, pulses, okhra, potato, cauliflower, onion, leafy vegetables, gourds and water melons could be cultivated in the past. Bags full of food used to be harvested during April," reminisced 50 year old GB. Availability of molluscs and edible wetland plants as well as Aeschynmene which provides fibre reportedly decreased substantially over the years.

According to the respondents, the swamp water seemed to have degraded in quality as well due to loss of its connection with Ganges over the last 15-20 years. This had increased the duration of waterlogging and created an unhygienic condition. "The swamp water is rotting. People get skin diseases now," says senior citizen DB while teenager $P$ remembered how clean the water used to be in the canal during his childhood when it was connected to Ganges "The water was so clear that if one dropped a coin, it would be visible right till it hit the bottom. I used to dive into the canal from the bridge to take a bath. The water has now become blackish especially since the last three to four years." The respondent's testimonies suggest that fish diversity and abundance had decreased substantially over the years, especially Nandus nandus, Ophisternon bengalense, Glossogobius giuris and Mystys vittatus as 65 year old DB shared. "I still remember how my grandmother used to come back with baskets full of crabs in the past which she used to sell for 2-3 INR/kg whereas now we sell them for 100 INR/kg," reminisced 49 year old SD implying that crabs had become scarce. Fish spawns were reported to be dying in the wetland as the outflow of the swamp water got blocked. Aquatic weeds and leaches had instead proliferated in recent times and the water had become unsuitable for irrigation. 52 year old $U$ shared, "We don't drink water from the swamp anymore."

The degradation in the quality of the wetland had changed the way of life in the village. GB, who is 50 years old now, shared that he did not have to go outside for work as a younger person as they could get expensive fish like Heteropneustes fossilis for free from the swamp as well as pulses and a variety of

Page $10 / 20$ 
vegetables. "Those days are gone now. If I go for fishing now, I will catch fish worth less than 250 INR whereas if I work as a hired labourer I will earn atleast 250-300 INR/day. Fish from the swamp was so integral to our diet. The fish catch used to be huge. Even after feeding the whole family, the remaining could be sold for 300-500 INR/day during monsoon." Similar sentiments were echoed by other respondents and many reported leaving agriculture and fishing due to lower economic returns and thus, being forced to work as hired labourers. Due to lower productivity, many had sold off their land to overcome financial shocks. "Businessmen buy these lands at lesser prices $(8,00,000-10,00,000$ INR/bigha) taking advantage of unemployed people who are in need of cash and thus sell them at a huge cost (2,00,000 - 3,00,000 INR/katha)," shared PS (35)[6]. Some land-owners also decided to convert parts of their water-logged land to small-scale aquaculture.

During the study year, the region received excessive rainfall due to cyclonic depressions over Bay of Bengal which further aggravated the situation. Due to the blockage of the channel connecting the wetland to the river, excess rain water could not flow out, prolonging the water logged situation. The standing water from the land usually starts receding by end of October yet GB's land remained waterlogged till mid-January, "In October the land must remain muddy but it has to lose its moisture after that if the onion yield is to be good. It is too late now." The calamity even disrupted age-old cultural practices as reported by 38 year old RB, "By this time okhra plants become upright and even starts flowering. It takes atleast 15-20 days for the seeds to germinate. As soon as they do, we celebrate Makar Sankranti, a festival that marks the onset of the new harvest, a 250 year old tradition. But where is the harvest to celebrate this year?"

\subsection{Drivers of change}

Respondents unanimously identified presence of factories as the main factor causing degradation of the Dankuni wetland. According to most respondents, the emergence of factories in the last 15-20 years coincided with the beginning of degradation and wetland shrinkage as they were constructed by filling up parts of the wetland. HT, a senior citizen, explained, "The swamp has shrunk to a fourth of what it used to be due to the construction of factories. 25 years back, this was all swamp," he said pointing to the horizon and beyond on both sides. 34 year old KT detailed, "The first factory was constructed in the wetland 15 years back. Gradually, other factories also emerged." ST added, "They dump sand, soil, ash and debris into the wetland everyday and this blocks the passage of water out of the swamp." PM further explained, "The discharged solid waste materials have accumulated in the canal connecting the wetland to Ganges, making it significantly shallow and the waters stagnant." The respondents mentioned that the sluice gate of the main canal was not functioning due to which wastewater released by the factories stayed locked inside the wetland. Large buffalo shelters constructed along the canal also added to the problems. "The cattle waste is discharged into the swamp. One can find syringes and broken pieces of glasses in the swamp nowadays," said 50 year old TB.

\subsection{Perceptions on threat mitigation}


Almost all respondents said that the only way to restore the health of the wetlands is by dredging the canal that connects the wetland to the river. They also reported that at various times they had informed local politicians and administrative officials of the dire situation of the wetlands but to almost no avail. "They created a small outlet after we agitated but that is not enough. The sluice gate of the main canal has to be repaired. It is broken and clogged with debris. Some of us went there to clean it up but did not succeed," said KK, himself a senior citizen. Respondents felt that the weed cleaning drives conducted by the panchayat did not yield desired results. Lamenting on failed mitigation actions, 70 year old HT said "There are so many factors due to which the swamp is dying. Just cleaning water hyacinth is not enough. We are unable to farm but our MLAs and MPs do not bother. Nowadays factories run the government so the government will work to benefit them." The respondents also thought that the onus of protecting the swamp lied with the local community as well. In this respect 32 year old ST stressed, "If the owners protest in unison, the government will have to respond. But if they sell off their land instead, how will the situation be rectified?" However, the views of 38 year old RB differed in this matter, "People do not raise their voices as this kind of destruction is being done by very powerful people at helm who have a lot of money. They will squash us like insects." In addition, lands belonging to community members were often sold off without their knowledge. Similar processes were at work in other villages surrounding the wetland, which led to its degradation on the one hand and impacted the livelihoods and living of dependent communities on the other.

[5] 1 INR= 0.013 USD

[6] 1 katha $=\sim 67 \mathrm{sq}$ metres, 1 bigha $=\sim .0013 \mathrm{sq} \mathrm{km}$

\section{Discussion}

Our study showed that villagers residing beside a peri-urban wetland, Dankuni complex situation in the rapidly urbanising Lower Gangetic Floodplains, perceived that the wetlands enhanced the quality of their lives, subsidized their living and provided livelihoods to vulnerable members of the community. However, development of this wetland complex due to dominant political-economic forces reportedly led to diminishing returns/services and had serious negative social implications including loss of livelihood, increased disaster risk and exposure to financial vulnerabilities.

We recorded eighteen ecosystem services of the Dankuni wetlands with twelve provisioning services such as edible crop farming (for example, paddy and vegetables), non-edible crop farming (jute), collection of wetland products such as fish, molluscs, edible wild plants, fibre, water, mud, bamboo, fuelwood and fodder. The wetland was found to subsidize the living costs of respondents. Vulnerable sections, especially landless widows and older residents, were solely dependent on the wetlands for subsistence and livelihood. Thus although local residents may be economically poor, many other dimensions of poverty had been circumnavigated, through procurement of fodder for cows, fuelwood, fibre, edible plants, house-building materials and molluscs, without any investment. Apart from this, the wetland also 
provided regulatory services (like flood control and water purification), supporting services (like nutrient retention and providing refuge for fish stocks) which sustained the provisioning services, and, cultural services that enhanced the quality of their lives. The dependence of local communities, especially of women and older residents on common natural resources such as wetlands, has in fact been well documented elsewhere (Ahmed et al. 2008; Mundoli et al. 2017; Sinthumule 2021).

However, the oral testimonies clearly suggested that there has been significant erosion in all ecosystem services over the last 15-20 years and especially in the last three to four years. This coincided with the emergence of factories during the same time span which according to locals were constructed by filling up the wetlands, thereby blocking the flow of water between the wetland and the river. Moreover, wastewater generated from the factories and debris from buffalo shelters had contributed to blocking the canal connecting the wetland to the Ganges. Over the years this process resulted in the contraction of the wetland to one-fourth of its original size and to its qualitative degradation. This reverberates with the situation in most South Asian countries where urbanisation and industrialization has degraded water sources and rivers (Sarkar et al. 2021).

Accumulation of untreated waste water and a loss of the wetland's connection with Ganges, had eroded the wetland's capacity to purify water and therefore impeded water usage for drinking and irrigation purposes. Fish abundance and diversity was especially affected due to degradation of the water quality. This affected local resident's access to nutritious food which they would need to buy instead. The decreasing capacity of the wetland to regulate floods affected farming in general and post-monsoon farming in particular during years of excessive and erratic rainfall such as in the study year. If the wetland is irreversibly damaged, the resident community will be forced to depend completely on external actors, with whom, their bargaining power is set to reduce to a large extent, as has been seen in the case of marginalized urban communities who depended on lake systems in the city of Bangalore, India, but were alienated by the development process (Unnikrishnan et al. 2016).

Even though wetlands act as nature-based solutions to treat wastewater, respondents perceived that the continuous release of untreated wastewater and detachment of the wetland's riverine connection due to unplanned development overwhelmed the wetland's functions, posed health hazards and prevented their access to clean water. In fact, unsustainable use of wetlands and their development have been known to impair wetland functions and permanently damage socio-ecological systems elsewhere in the world (Vilardy et al. 2011; Jaramillo et al. 2018). Jaramillo et al. (2019) identified the improvement of water quality and adoption of 'wise-use' of wetlands as central to achieving a range of SDGs covering environmental health, equity, human well-being and justice. Respondents believed that water quality of the wetland could be improved if the canal connecting it to river Ganges was dredged which would allow the polluted water of the swamp to flow out and tidal waters to flow in. It is pertinent to note here that wetland restoration with inputs from local communities has been encouraged because such communities have a better understanding of the ecosystem due to their closer association with it (Finlayson et al. 2019). 
Local residents also perceived that a syndicate between local politicians, administrators and factory owners was working to the detriment of the wetland and dependent human communities in Jhakari and adjoining villages. Often the land was taken away from members of the community without their consent or knowledge, while some sold off their land due to diminishing returns as a result of the overall degradation of the wetland. Such impacts of short term political and economic benefits outweighing long-term ecological and social vulnerability in the context of local wetlands, have been observed in two case studies from Australia (Della Bosca and Jillespie 2020).

The degradation of wetland was perceived by villagers as an attack on a self-sustaining ecosystem which gave them prosperity, autonomy and prestige. From being self-dependent, people felt that they were increasingly being pushed towards relying on external actors, urban centres and working as labourers for financial and physical security. Urbanisation has been known to cause the loss of these affective dimensions and silence voices of the vulnerable, especially women and older citizens (Mundoli et al. 2017).

According to local residents, the corporate-politician syndicate had vested interests in degrading the wetland further so that the land can be diverted easily for further development and urbanisation. Negligence of environmental policies and suppression of the voice of vulnerable groups have been identified as a common practice in developing countries where cross-sectoral policy integration for environmental protection is non-existent or limited and corruption is rampant (Hettiarachchi et al. 2015). Our study, through the testimonies of local community members strongly asserted the need to increase government accountability for protection of wetlands in human-dominated landscapes that face twin threats of poor implementation of law and pursuit of development at the cost of sustainable and resilient futures. This work needs to be upscaled in the future to fully understand the impact of ecologically harmful development on communities living around wetlands and complemented with quantitative assessments.

\section{Conclusion}

Jhakari, where we situated our study to understand how degradation of a once well-functioning wetland affected local communities is not an exceptional case in hand. The Lower Gangetic Floodplains are replete with a variety of wetlands that sustain the livelihoods and culture of many communities both in India and Bangladesh. The life and livelihoods of local communities that have been disrupted to different degrees due to development induced rapid degradation of such wetlands need to be foregrounded in academia and institutional mechanisms to mitigate these changes needs to examined.

These socio-ecological changes and their impacts clearly suggest that sustainability remains a rhetoric and distant dream in the development policies and practices. Wetlands, especially marshlands remain in a grey zone of global and local legal safeguards and are most amenable to fall victim to rapid unchecked industrial development. Popular opinion often point towards rising population as the sole cause for ecosystem changes; however, the example of Jhakari suggests that we need to hold (mal)development 
models accountable for such negative changes. 'Precautionary' as well as the 'polluter-pays' principle should become bedrock of industrial development model so that negative impacts on people depending materially and affectively on wetlands and other ecosystems can be minimized.

Policy making as well as academic research on ecosystem changes should integrate people's testimonies and their stories as evidence of those changes. Such integration of local knowledge will help in foregrounding place-based sustainability models.

\section{Declarations}

Funding: The authors declare that no formal grant was received during preparation of this manuscript. The non-profit conservation NGO Wildlife Conservation Trust donated generously to the project.

Competing interests: The authors have no relevant financial or non-financial interests to disclose

Author contributions: All authors contributed equally to study conception, design, data collection, analysis and manuscript preparation

Data availability: The data collected were in the form of qualitative interviews and these testimonies contain sensitive information about our respondents' social profile and life. So, these dataset cannot be uploaded to external repositories due to ethical concerns. However, the testimonies are available to the corresponding author and if requested, can be shared upon reasonable request.

\section{References}

1. Adekola O, Mitchell G (2011) The Niger Delta wetlands: threats to ecosystem services, their importance to dependent communities and possible management measures. International Journal of Biodiversity Science, Ecosystem Services \& Management7(1): 50-68

2. Adhya T, Dey P, Das U, Hazra P (2011) Status survey of Fishing Cat (Prionailurus viverrinus) in Howrah and Hooghly, West Bengal. Intermediate report submitted to the small grants programme, WWF, India. WWF India

3. Adhya T (2015) Martyr and a court ruling: wetlands in Howrah still ravaged by real estate. Down To Earth. https://www.downtoearth.org.in/blog/martyr-and-a-court-ruling-41796. Accessed 28 June 2020

4. Ahmed I., Deaton BJ, Sarker R, Virani T (2008) Wetland ownership and management in a common property resource setting: a case study of Hakaluki Haor in Bangladesh. Ecological Economics 68(12): 429-436

5. Azarath J, Banth P, Azarath H, Selvan V (1988) Impact of urbanization on the status of mangrove swamps in Madras. In: Hook DD et al (ed) The ecology and management of wetlands, Volume 2: Management Use and Value of Wetlands. Timber Press, Portland Oregon, pp 225-233 
6. Schuyt K, Brander L (2004) Living waters: the economic values of the world's wetlands.

(Environmental Studies). WWF. http://www.mendeley.com/research/living-waterthe-economic-valuesworlds-wetlands. Accessed 26 November 2021

7. Chalov S, Thorslund J, Kasimov N, Aybullatov D, llyicheva E, Karthe D et al (2017) The Selenga river delta: a geochemical barrier protecting Lake Baikal waters. Regional environmental change 17(7): 2039-2053

8. Davidson NC (2014) How much wetland has the world lost? long-term and recent trends in global wetland area. Marine and Freshwater Research 65(10): 934-941

9. Das M, Das A (2019) Estimation of ecosystem services (EESs) loss due to transformation of Local Climatic Zones (LCZs) in Sriniketan-Santiniketan Planning Area (SSPA) West Bengal, India. Sustainable Cities and Society, 47, p.101474. doi:10.1016/j.scs.2019.101474

10. Della Bosca H, Gillespie J (2020) Bringing the swamp in from the periphery: Australian wetlands as sites of climate resilience and political agency. Journal of Environmental Planning and Management 63(9): 1616-1632

11. Fennessy MS, Wardrop DH, Moon JB, Wilson S, Craft C (2018) Soil carbon sequestration in freshwater wetlands varies across a gradient of ecological condition and by ecoregion. Ecological Engineering 114: 129-136

12. Finlayson CM, Davies GT, Moomaw WR, Chmura GL, Natali SM, Perry JE, Roulet N, Sutton-Grier AE (2019) The second warning to humanity-providing a context for wetland management and policy. Wetlands 39(1):1-5

13. Gardner RC, Finlayson C (2018) Global wetland outlook: state of the world's wetlands and their services to people. Ramsar Convention Secretariat, Gland, Switzerland

14. Ghosh D, Sen S (1987) Ecological history of Calcutta wetland conversion. Environmental Conservation 14(3): 219-226

15. Gopal B (2013) Future of wetlands in tropical and subtropical Asia, especially in the face of climate change. Aquatic sciences 75(1): 39-61

16. Hazra P, Sinha A, Mondal P, Khan TN (2012) Calendar-effects and temperature-impacts in migratory waterbirds at three tropical Indian wetlands. Acta oecologica 43: 60-71

17. Hettiarachchi M, Morrison TH, McAlpine C (2015) Forty-three years of Ramsar and urban wetlands. Global Environmental Change, 32: 57-66

18. Jaramillo F, Licero L, Åhlen I, Manzoni S, Rodríguez-Rodríguez JA, Guittard A, Hylin A, Bolaños J, Jawitz J, Wdowinski S et al (2018) Effects of hydroclimatic change and rehabilitation activities on salinity and mangroves in the Ciénaga Grande de Santa Marta, Colombia. Wetlands 38: 755-767

19. Jaramillo F, Desormeaux A, Hedlund J, Jawitz JW, Clerici N, Piemontese L et al (2019) Priorities and interactions of sustainable development goals (SDGs) with focus on wetlands. Water 11, 619 doi:10.3390/w11030619

20. Kundu N, Chakraborty A (2017) Dependence on ecosystem goods and services: a case study on East Kolkata Wetlands, West Bengal, India. In Prusty AK, Chandra R, Azeez PA (eds.) Wetland science: 
perspectives from South Asia. Springer, New Delhi, pp 381-405

21. McCartney M, Rebelo LM, Senaratna Sellamuttu S, De Silva S (2010) Wetlands, agriculture and poverty reduction (Vol. 137). IWMI

22. Mitsch WJ, Bernal B, Nahlik AM, Mander Ü, Zhang L, Anderson CJ et al (2013) Wetlands, carbon, and climate change. Landscape Ecology 28(4): 583-597

23. Ministry of Environment, Forest and Climate Change. 2017. Wetlands (Conservation and Management) Rules, 2017. MoEFCC. http://envfor.nic.in/content/gsr-1203e-wetlands-conservationand-management-rules-2017. Accessed 5 July 2020

24. Mundoli S, Unnikrishnan H, Nagendra H (2017) The "Sustainable" in smart cities: ignoring the importance of urban ecosystems. Decision 44(2): 103-120

25. National Remote Sensing Centre (2010) Wastelands Atlas of India 2010. Department of Land Resources, Ministry of Rural Development, Delhi

26. Pedersen E, Weisner SE, Johansson M (2019) Wetland areas' direct contributions to residents' wellbeing entitle them to high cultural ecosystem values. Science of the Total Environment 646: 13151326

27. Ramsar Convention Secretariat (2016) The fourth Ramsar strategic plan 2016-2024. Ramsar handbooks for the wise use of wetlands, 5th edition, vol. 2. Ramsar Convention Secretariat, Gland, Switzerland

28. Russi D, Ten Brink P, Farmer A, Badura T, Coates D, Förster J, Kumar R, Davidson N (2013) The Economics of Ecosystems and Biodiversity for Water and Wetlands. IEEP, London and Brussels; Ramsar Secretariat, Gland

29. Sarkar B, Keya KN, Mahir Fl, Nahiun KM, Shahida S, Khan RA (2021) Surface and ground water pollution: causes and effects of urbanization and industrialization in South Asia. Scientific Review 7(3): $32-41$

30. Sato T, Qadir M, Yamamoto S, Endo T, Zahoor A (2013) Global, regional, and country level need for data on wastewater generation, treatment, and use. Agricultural Water Management, 130, 1-13

31. Seifollahi-Aghmiuni S, Nockrach M, Kalantari Z (2019) The potential of wetlands in achieving the sustainable development goals of the 2030 Agenda. Water 11(3): 609

32. Sinha S, Basu LK, Halder A, Chakraborty T (2013) A case study on the changing pattern of wetlands in West Bengal and its possible impacts on groundwater resources. Workshop on Sustainable development and management of ground water in West Bengal and future of irrigation vis-a-vis arsenic contamination in ground water. Central Ground Water Authority \& Central Ground Water Board Eastern Region, Kolkata. 19 February 2013

33. Sinthumule NI (2021) An analysis of communities' attitudes towards wetlands and implications for sustainability. Global Ecology and Conservation 27 https://doi.org/10.1016/j.gecco.2021.e01604

34. Smardon RC (2009). Sustaining the Worlds Wetlands. Springer, London

35. Turner K (1991) Economics and wetland management. Ambio 20(2): 59-63 
36. Unnikrishnan H, Mundoli S, Nagendra H (2016) Down the drain: the tragedy of the disappearing urban commons of Bengaluru. South Asian Water Studies 5(3): 7-11

37. UN (United Nations) (2008) World urbanization prospects: the 2007 revision. United Nations, Department of Economic and Social Affairs, Population Division, New York

38. UN-Water (2015) Wastewater management: a UN-water analytical brief. UN-Water

39. Van Asselen S, Verburg PH, Vermaat JE, Janse JH (2013) Drivers of wetland conversion: a global meta-analysis. PloS one 8(11): e81292

40. Vilardy SP, González JA, Martín-López B, Montes C (2011). Relationships between hydrological regime and ecosystem services supply in a Caribbean coastal wetland: a social-ecological approach. Hydrological Sciences Journal 56(8): 1423-1435

41. Walpole M, Davidson N (2018) Stop draining the swamp: it's time to tackle wetland loss. Oryx 52(4): 595-596

42. WWAP. (United Nations World Water Assessment Programme) (2012). The United Nations World Water Development Report 2012: managing water under uncertainty and risk. Paris: UNESCO

43. WWAP. (2017). The United Nations World Water Development Report 2017. Wastewater: the untapped resource. Paris: UNESCO

\section{Figures}




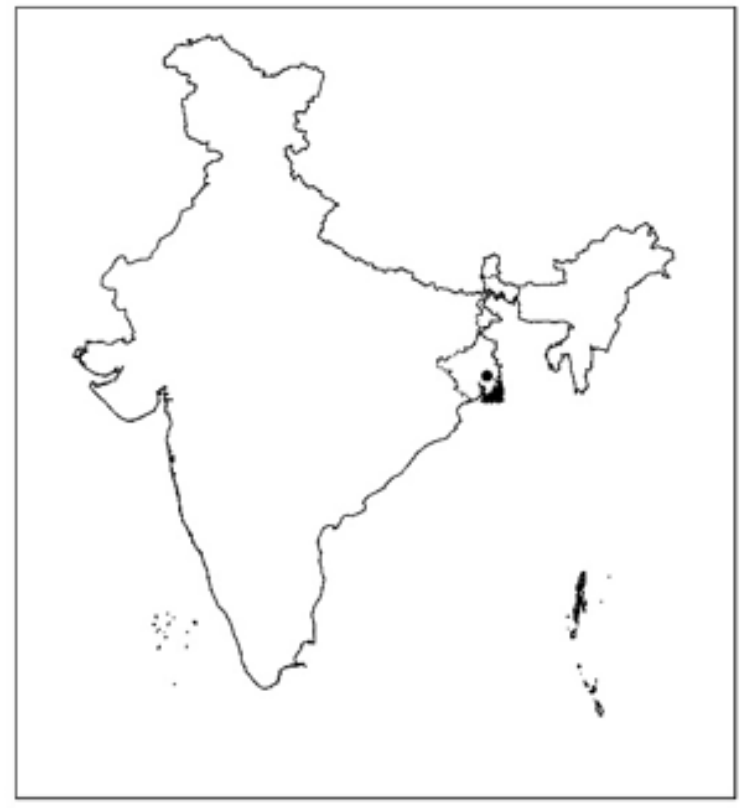

\section{Legend}

..... Outline of Jhakari

Outline of Dankuni Wetlands

- Dankuni

West Bengal

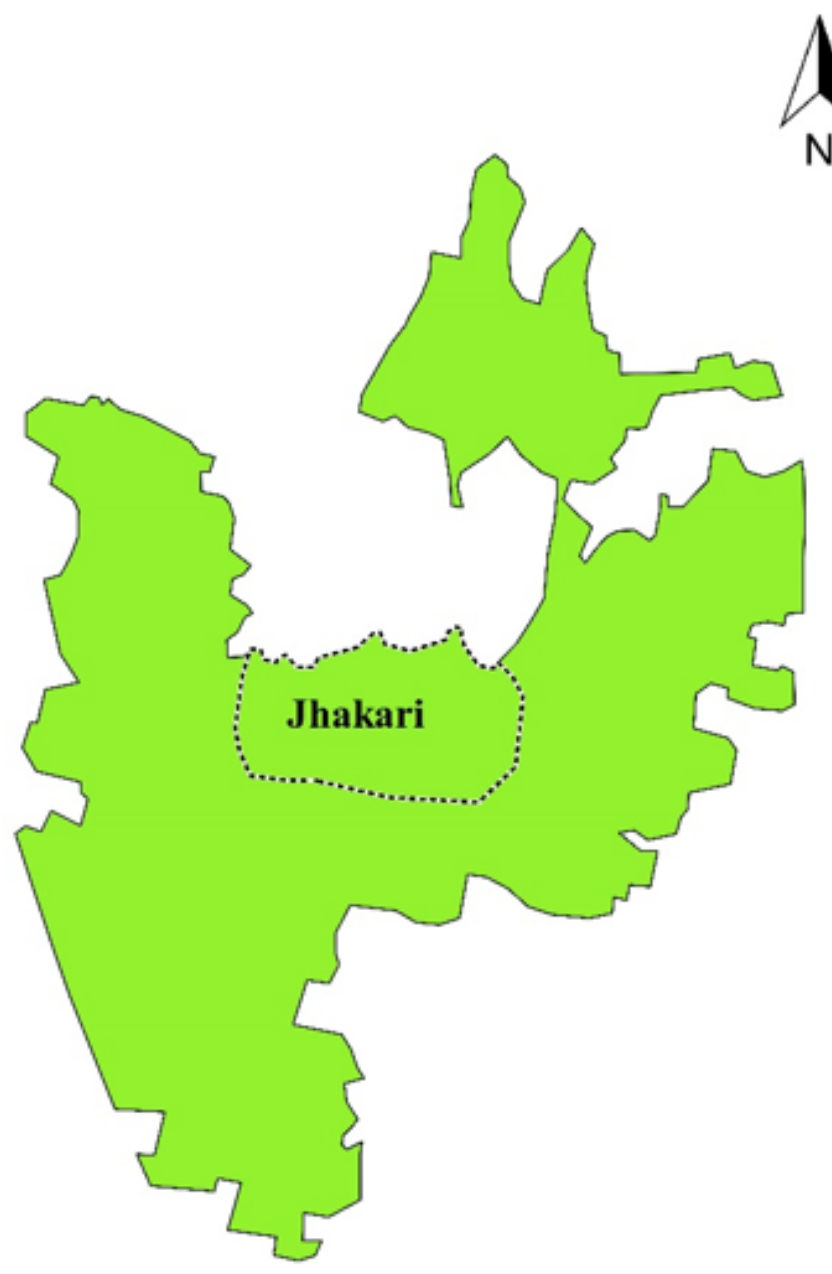

\section{Figure 1}

Location of study site in West Bengal, India 


\section{Products obtained from the wetland}

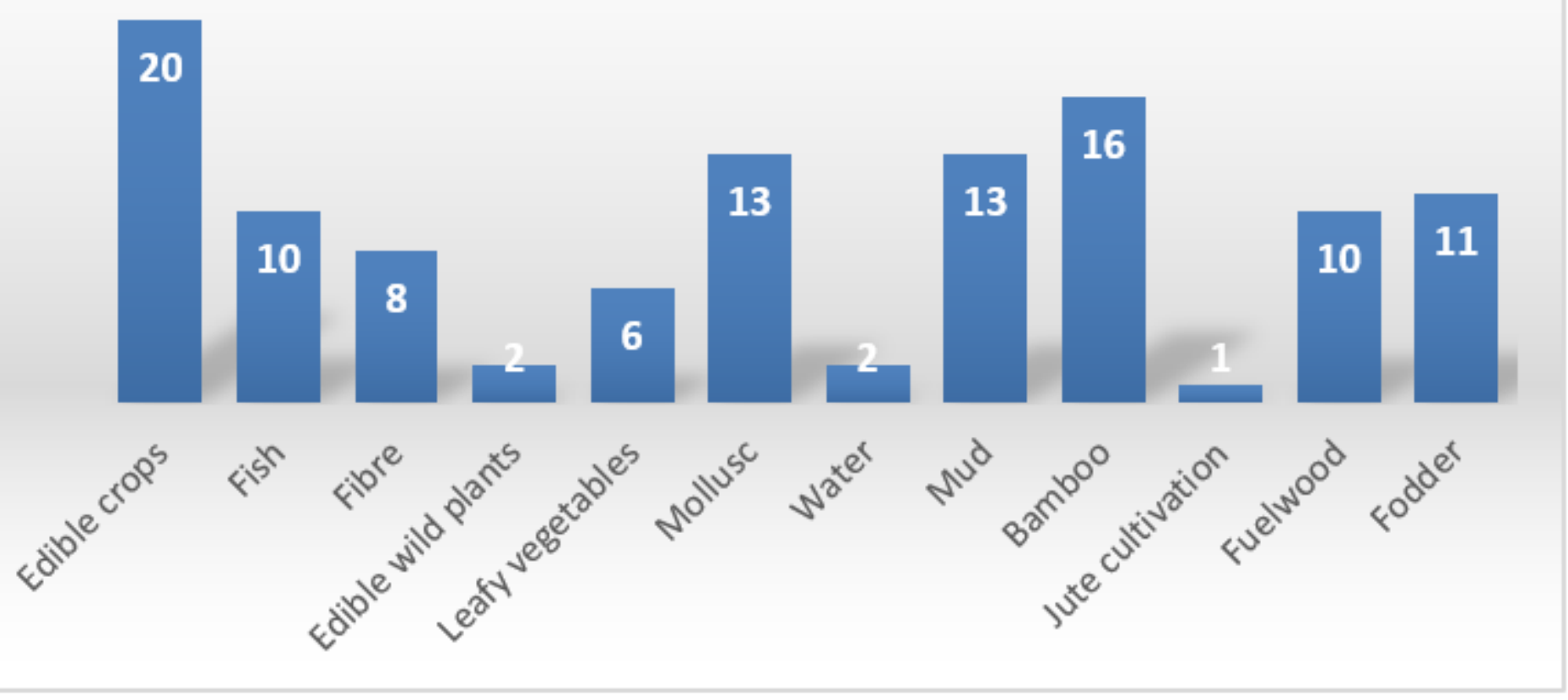

Figure 2

The relative importance of wetland products for interviewees with the numbers representing the frequency of a particular usage as mentioned across interviews 